\title{
Election Cycles and Stock Market Reaction: International Evidence*
}

\author{
Cheolbeom Park** and Jiyoun An***
}

\begin{abstract}
This study investigates movements of stock market volatility during election periods (the six months before and after an election) using data from 16 countries. The main findings of this study are (1) volatility declines over time as elections approach, (2) the level of volatility during election periods is lower than that during nonelection periods, and (3) volatility rises quickly during election months and immediately after the elections. The first and second findings confirm assertions made in previous studies, such as Pantzalis, Stangeland, and Turtle (2000) and Wisniewski (2009), regarding the dynamic pattern of stock market volatility during election years.
\end{abstract}

Keywords: Elections, Stock market volatility, Uncertainty, International evidence

\section{INTRODUCTION}

Stock market volatility plays an important role in investors' decision making processes in practice as well as in theoretical models of economics. However, our understanding of this volatility has improved little since the seminal works by Shiller (1981) and Schwert (1989). Shiller (1981) demonstrated that stock prices are too volatile to be explained by movements of dividends, and Schwert (1989) reported that macroeconomic variables and financial variables can explain only a small portion of the variation in the volatility. In this study, we attempt to enhance the understanding of

* This paper is a revised version of the Korea Institute for International Economic Policy working paper 12-04.

** Professor, Department of Economics, Korea University, 145 Anam-Ro, Seongbuk-Gu, Seoul 136-701, Tel: 82-2-3290-2203. Email: cbpark_kjs@korea.ac.kr.

*** Corresponding author: Assistant Professor, Department of International Studies, Kyung Hee University, 1732 Deogyoung-daero, Giheung-gu, Yongin-si, Gyeonggi-do 446-701, Tel: 82-31-201-3884, Fax: 82-31-201-2281, Email: ja256@khu.ac.kr.

Manuscript received July 13, 2015; out for review August 3, 2015; review completed August 28, 2015; accepted October 23, 2015.

The Korean Journal of Policy Studies, Vol. 30, No. 3 (2015), pp. 23-40.

(C) 2015 by the GSPA, Seoul National University 
the volatility by examining stock market volatility around election times in 16 countries. Elections are important political events which determine the direction of future economic management during the term. Changes in policies, which are determined by election outcomes, can influence not only consumers' welfare, but also firms' profits. Because of this, it is natural for investors in the market to predict election outcomes well before election days. An election itself is regarded as an additional factor that impacts volatility around elections. Investors may adjust their portfolio when they have information about a pattern of volatility movements around elections. In addition, if stock market volatility exhibits certain trends during election periods, it will be reflected not only in stock prices, but also in option prices, which is valuable information for investors.

In spite of the importance of stock market volatility, research on volatility during election periods is scant. Few papers study whether government or presidential election partisanship affects the stock market volatility (Leblang and Mukhurjee, 2004 and 2005; Döpke and Pierdzioch, 2006). ${ }^{1}$ In particular, Leblang and Mukhurjee (2004) find that stock market volatility decreases when traders expect a Democratic party victory using the United States election and stock market data. However, Döpke and Pierdzioch (2006) find no evidence that there is election cycles in the German stock market. Without examining return volatility directly, some studies have made interpretations regarding movement of stock prices during election periods based on conjecture for dynamic patterns of the volatility. For example, Pantzalis et al. (2000) report that stock prices rise as elections approach, and surmise that these increases are the result of diminished uncertainty as elections draw near. Also, Wisniewski (2009) has interpreted the overpricing of stock prices during election periods, reported in Herbst and Slinkman (1984), Huang (1985), Gärtner and Wellershoff (1995) and Wisniewski (2009), as the result of the lower risk perceived by investors during election campaigns. Wisniewski (2009) posits that the perceived risk over election periods tends to be lower than that during non-election periods due to auspicious promises and optimistic policies made by politicians in the midst of election campaigns. He argues that this perception of lower risk is the main reason for overpricing during election periods. The main purpose of our study is to examine whether the evolution of stock market volatility during election periods is consistent with the assertions in Pantzalis et al. (2000) and Wisniewski (2009). That is, we are assessing directly whether the volatility declines as elections approach (the premise in Pantzalis et al. (2000)) and whether the volatility before elec-

1. Other studies focus on the relationship between stock market performance or macroeconomic policies and political events. For example, Chung and Jung (2009) find that monetary and fiscal policy outcomes are related to political business cycles. 
tions tends to be lower than the volatility during non-election periods (the premise in Wisniewski (2009)). In addition, Bialkowski, Gottschalk, and Wisniewski (2008) find that stock markets are extremely vulnerable in terms of volatility around elections, which may reflect surprise at election outcomes. We will also examine whether this phenomenon by Bialkowski et al. (2008) is replicable in the 16 countries considered in this study. In particular, our work contributes to the literature by examining the most general elections of the sample countries since the World War II. Pantzalis et al. (2000) and Bialkowski et el. (2008) only consider elections during 1972-1995 and 1980-2004, respectively. Their sample periods may show sample selection biases. Our data includes a longer time span from 1950 to 2006 which are relatively free from sample selection biases.

After estimating stock market volatility under the GARCH $(1,1)$ model, we run panel regressions of the estimated volatility on time-dummy variables indicating difference in time election months. We find that the volatility declines as election months approach, rises rapidly during the election month and immediately after elections, and then stabilizes around the normal level. This pattern in the volatility is robust regardless of whether other control variables are included, whether the rightist (or leftist) party wins the election, and whether the pre- or post- 1980 observations are used in the analyses. This pattern seems intuitive and consistent with the argument in Pantzalis et al. (2000) because the volatility lowers as election days approach. The finding that the level of the return volatility before elections is lower than that during non-election periods is also aligned with the argument in Wisniewski (2009), based on the psychological model by Loewenstein et al. (2001). Finally, the behavior of the volatility during election months and immediately following elections is consistent with the findings in Bialkowski et al. (2008).

In order to present these findings, our study is organized as follows: Section 2 provides a brief discussion of our econometric methodology regarding how to estimate the return volatility and how to determine the evolution of the volatility around election periods; Section 3 presents the data used in our study and summary statistics for important political and economic variables; main empirical results are reported in Section 4, and concluding remarks are offered in Section 5.

\section{METHODOLOGY}

Several approaches for measuring stock market volatility have been proposed. Although each approach has strengths and weaknesses, in this study we employ a GARCH $(1,1)$ model to estimate the volatility. Since its introduction by Engle (1982) 
and Bollerslev (1986), GARCH models have been quite popular in the literature and are widely used in predicting future volatility. GARCH models enable us to estimate volatility using monthly stock return data, while estimating realized volatility or implied volatility requires additional higher frequency stock return data or option price data. Thus, we have chosen the GARCH $(1,1)$ model because it is practical as well as reasonable. ${ }^{2}$ We estimate the volatility for each country according to the following GARCH $(1,1)$ representation:

$$
\begin{aligned}
& r_{i, t}=\alpha_{i}+\varepsilon_{i, t}, \varepsilon_{i, t} \sim N\left(0, h_{i, t}\right) \\
& h_{i, t}=\gamma_{0}+\gamma_{1} h_{i, t-1}+\gamma_{2} \varepsilon_{i, t-1}^{2}
\end{aligned}
$$

where $r_{i, t}$ is the stock market return for country $i$ on day $t, \varepsilon_{i, t}$ denotes the countryspecific shocks to stock returns, and $h_{i, t}$ denotes the conditional variance of stock market returns. We jointly estimated equations 1 and 2 using the maximum likelihood estimation method.

Once we obtained the estimates of stock return volatilities $\left(h_{i, t}\right)$ under the conditions described by equations 1 and 2, we ran an unbalanced panel regression with country fixed effects to examine the dynamic pattern of volatility for the period from the six months before to the six months after an election.

$$
h_{i, t}=\beta_{i}+\sum_{k=-6}^{6} \delta_{k} D_{i, k, t}+\sum_{j} \theta_{j} X_{i, j, t-1}+u_{i, t}
$$

where $\beta_{i}$ represents country-specific time-invariant factors and $X_{i, j, t}$ denotes control variables other than $D_{i, k, t} D_{i, k, t}$ is a dummy variable that is set as one if time $t$ is $k$-month away from an election in country $i$ and as zero otherwise. Hence, $\delta_{k}$, the coefficients for $D_{i, k, t}$, will reveal the dynamic pattern of the volatility from six months before six months after an election. In addition to the dynamic pattern of the volatility, $\delta_{k}$ shows the relative magnitude of the volatility over the six months before and after an election compared with the average of the volatility during non-election periods. ${ }^{3}$ Since elections are infrequent events, we have employed a panel analysis of 16 countries to compensate for the inevitably small sample sizes that the analysis of just one country would yield.

2. Monthly stock return volatilities can be also estimated by calculating standard deviations of stock returns with a fixed rolling window such as from the previous six months to the current month. However, standard deviation method includes past information in its calculation which increases serial correlation issues.

3. Non-election periods are time periods that do not fall between the half year before an election and the half year after the election. 
The 16 countries are Australia, Austria, Belgium, Canada, Denmark, Finland, France, Germany, Greece, Italy, Japan, the Netherlands, Spain, Sweden, the United Kingdom and the United States. Our dummy variable approach clearly shows whether there are changes in stock return volatilities during election periods. If $\delta_{k}$, the coefficients for $D_{i, k, t}$ from $k=-3$ to -1 , are statistically negative, it implies that stock market volatilities are lower from three months to one month before elections than during nonelection periods. Moreover, variables reflecting economic crises or other stock market events can be easily included in regressions. Pantzalis et al. (2000) and others employ event studies approach. However, event studies often show the dynamic pattern of the volatilities or stock returns with a short period of time (less than 30 days).

\section{DATA}

Initial political variable data sample are derived from a dataset compiled by Duane Swank. ${ }^{4}$ Swank's dataset covers 21 countries from 1950 to 2006, and contains election dates for each of those countries and election outcomes such as which party won for each election. Swank (2010) classifies various political parties in OECD countries into three categories - leftist, centrist, and rightist parties - and reports each party's cabinet portfolios as a percentage of all cabinet portfolios. We use this cabinet portfolio percentage to indicate which party, leftist or rightist, has won each of those elections. When constructing election outcome variables, we consider the centrist party as the leftist. ${ }^{5}$ For example, in the United States, Republicans are considered the rightist party and Democrats the leftist party.

International stock market variables are obtained from the Global Financial Database and those variables include: monthly total stock market return index (close), dividend yield, price to earnings (PE) ratio, current exchange rate, 10-year government bond yield, 3-month Treasury bill yield, and consumer price index. The Global Financial Database provides stock market and economic data over a long time period (over 200 years) for many countries, whereas other financial database sources (e.g. Datastream) contain international data that are mostly from the 1980s. We sample data starting from 1950, as it is far less risky in terms of sample period selection bias. We require that each observation include the variables listed above. Moreover, countries which do not have sufficient stock market data over time are removed from analyses. As such, there are 16 countries included in our analysis sample with data from the period 1950

4. See http://www.marquette.edu/polisci/faculty_swank.shtml.

5. Thus, this classification could be considered as the rightist versus the non-rightist. 


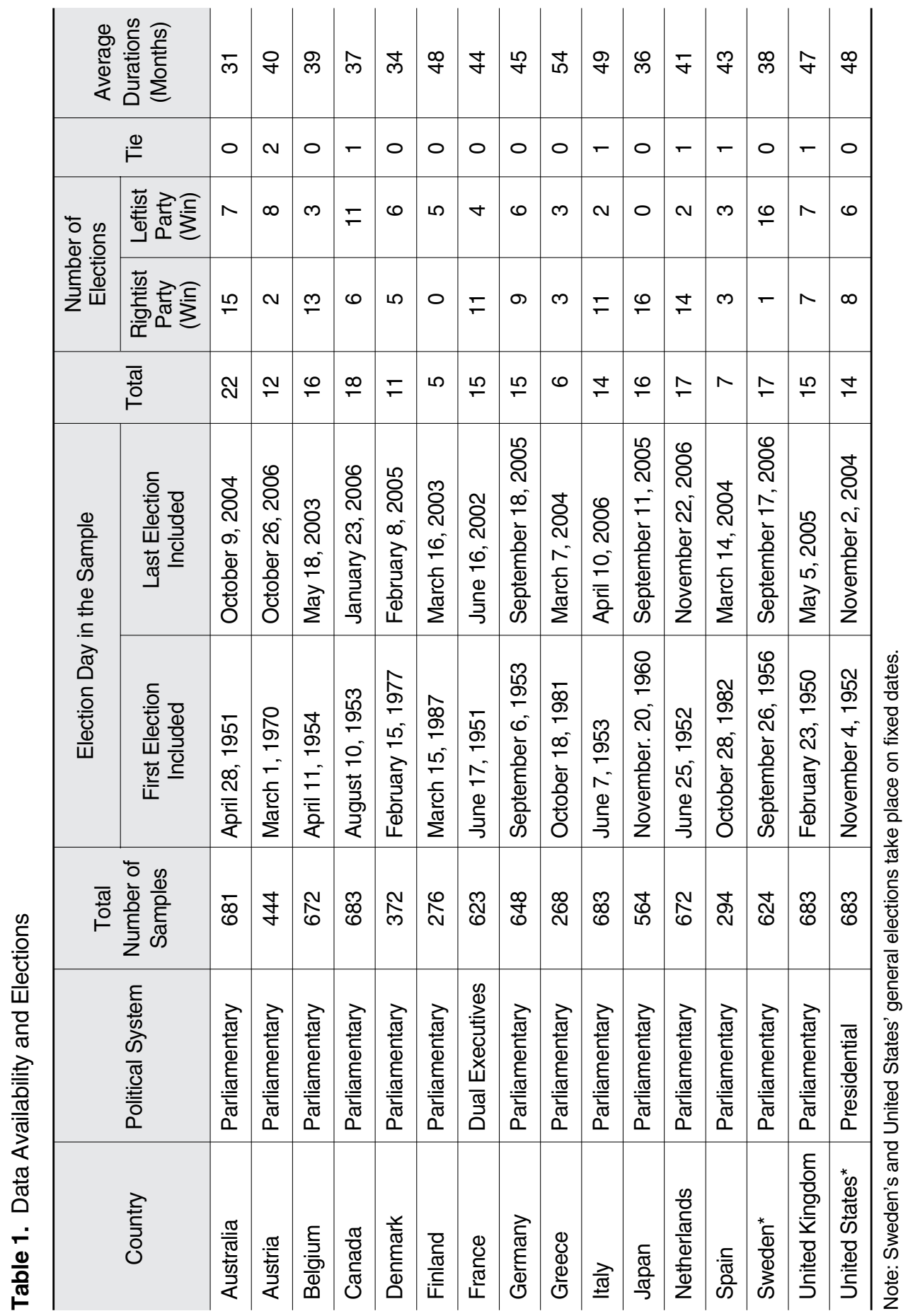


to 2006.

Prior to conducting regression analyses, several variables are calculated. Real stock returns are the log difference of stock return index minus inflation rate. Inflation rate is the log difference of consumer price index. Term spread is the difference between 10year government bond yields and 3-month Treasury bill yields. Relative interest rate is the difference between 3-month Treasury bill yield and its one-year moving average.

Summary statistics for political systems and elections in the 16 countries are presented in table 1. All countries have adopted a parliamentary system except France and the United States. France has a dual executives system, while the United States has a presidential system. The sample periods for most countries start from the $1950 \mathrm{~s}$ and are dictated by the subset of data available between the Global Financial Database and Swank's dataset. table 1 also shows the number of elections won by the rightist party and the number of elections won by the leftist party. Those numbers vary greatly across countries, possibly reflecting political preference in those countries. For example, the rightist party in Japan has won all the elections in the sample, whereas the leftist party has been overwhelmingly popular in Finland and Sweden. The average duration between two consecutive elections lies between 31 months and 54 months, which implies that elections have been held every 2.5 to 4.5 years, on average.

Table 2. Descriptive Statistics

\begin{tabular}{c|c|c|c|c|c|c}
\hline Variables & Types & Mean & $\begin{array}{c}\text { Standard } \\
\text { Deviation }\end{array}$ & $\begin{array}{c}\text { 25th } \\
\text { Percentile }\end{array}$ & Median & $\begin{array}{c}\text { 75th } \\
\text { Percentile }\end{array}$ \\
\hline \multirow{4}{*}{$\begin{array}{c}\text { real monthly } \\
\text { stock returns } \\
\text { (annualized) }\end{array}$} & total & 0.07 & 0.64 & -0.25 & 0.10 & 0.44 \\
\cline { 2 - 7 } & parliamentary & 0.07 & 0.65 & -0.25 & 0.10 & 0.44 \\
& dual executives & 0.08 & 0.50 & -0.21 & 0.10 & 0.41 \\
& rightist party wins & 0.06 & 0.64 & -0.31 & 0.11 & 0.50 \\
\cline { 2 - 7 } & leftist party wins & 0.08 & 0.59 & -0.25 & 0.10 & 0.43 \\
\cline { 2 - 7 } & pre-1980 & 0.13 & 0.05 & 0.10 & 0.13 & 0.17 \\
& post-1980 & 0.23 & 0.24 & 0.13 & 0.17 & 0.24 \\
\hline \multirow{4}{*}{ stock market } & total & 0.21 & 0.21 & 0.12 & 0.16 & 0.21 \\
\cline { 2 - 7 } volatility & parliamentary & 0.21 & 0.22 & 0.12 & 0.16 & 0.21 \\
\cline { 2 - 7 } & presidential & 0.18 & 0.13 & 0.11 & 0.16 & 0.19 \\
\cline { 2 - 7 } & rightist party wins & 0.23 & 0.22 & 0.12 & 0.16 & 0.22 \\
\cline { 2 - 7 } & leftist party wins & 0.18 & 0.13 & 0.11 & 0.15 & 0.20 \\
\cline { 2 - 7 } & pre-1980 & 0.04 & 0.53 & -0.25 & 0.06 & 0.36 \\
& post-1980 & 0.10 & 0.71 & -0.26 & 0.13 & 0.49 \\
\hline
\end{tabular}


Table 2 reports the descriptive statistics for aggregate stock returns and volatility estimated under the GARCH $(1,1)$ model. The average of stock returns across the 16 countries over the sample period is approximately $7 \%$ a year, while the median of stock returns is approximately $10 \%$. These values do not appear to vary based on political systems (parliamentary system, presidential system, or dual executives system) or on whether the political power is held by the rightist or leftist party. However, the average of stock returns during the post-1980 period is much higher than that during the pre-1980 period. The average of stock returns during the post-1980 period is $10 \%$, while the average of stock returns during the pre-1980 period is only $4 \%$.

The second row of table 2 reports summary statistics for volatility, which shows a similar pattern compared to that of average stock returns. Similar to the stock returns, the summary statistics of the estimated volatility do not vary based on political systems or on which party holds political power. We also note a large difference in the volatilities before and after 1980 . The average volatility during the post-1980 period is 0.23 , while during the pre-1980 it is 0.13 . In summary, stock markets from the 16 countries show higher stock returns and higher volatility after 1980 .

Figure 1 plots the U.S. stock return volatilities from January 1991 to December 2006, which are calculated using GARCH $(1,1)$. The plotted period includes four elections from 52nd to 55th presidential election. The stock return volatilities in the period before the election shows clearly declining trends in three cases (52nd, 54th, 55th), which suggests a declining relationship between stock return volatilities and election cycles.

Figure 1. United States Election Cycles and Stock Market Volatility

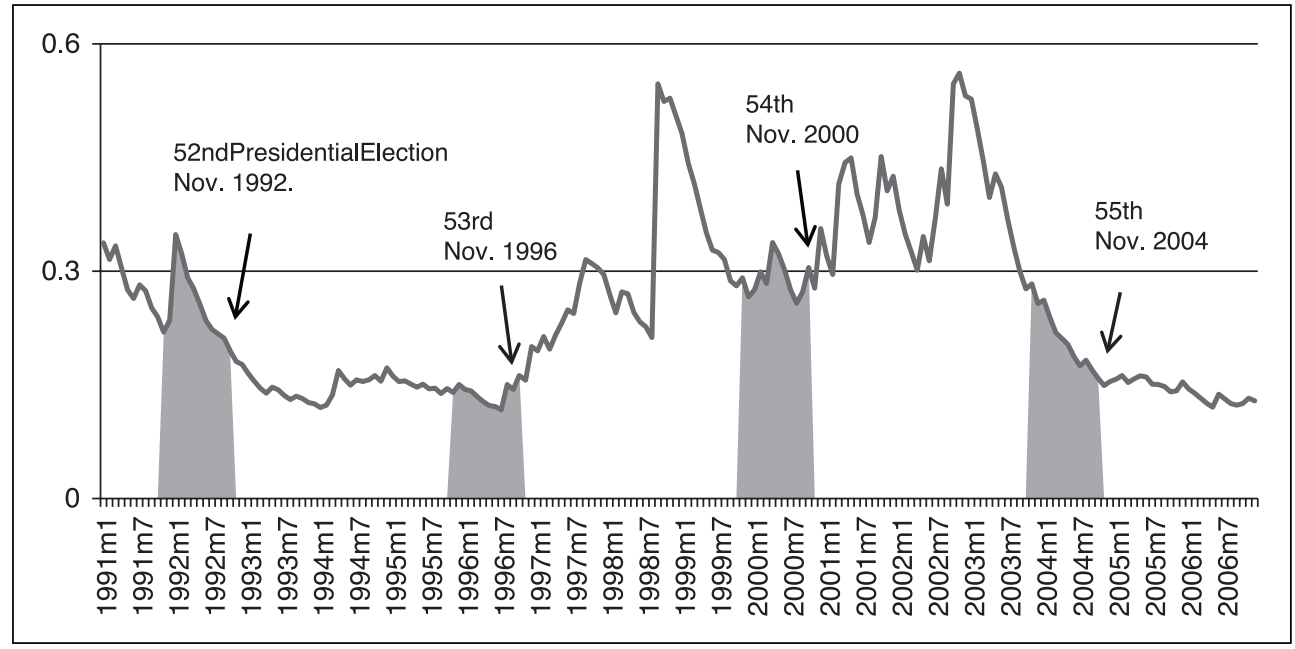

Note: The red area indicates the 12-mont periods before the presidential election month. 


\section{EMPIRICAL ANALYSIS}

\section{Stock Market Volatility during Election Years}

The main goal of our study is to investigate the dynamic pattern of the volatility in the six months before and after an election. From this investigation, we can assess whether the conclusions regarding the volatility made in previous studies are realistic and plausible. For this purpose, we established dummy variables indicating the time difference between the election months over the one-year period around it. We regress the estimated return volatility on these dummy variables along with other control variables, and assess the movements of the coefficients. The results are presented in table 3 . In the first column of table 3 , we have run a panel regression of the volatility on only the time-dummy variables and country-dummy variables so as to capture timeinvariant specific factors in individual countries. As shown in the first column, the coefficients of the dummy variables before an election are largely negative and become significant at the $10 \%$ level from four months to one month before the election. From the election month on, these coefficients rise initially, and then become insignificant and fluctuate around zero.

Table 3. Main Regressions

\begin{tabular}{l|l|l|l}
\hline \multirow{2}{*}{ Variables } & \multicolumn{3}{c}{ All Samples } \\
\cline { 2 - 4 } & \multicolumn{1}{c|}{$(1)$} & $(2)$ & $(3)$ \\
\hline \multirow{2}{*}{6 months (before) } & -0.023 & -0.022 & -0.023 \\
& $(0.02)$ & $(0.02)$ & $(0.02)$ \\
\hline \multirow{2}{*}{5 months (before) } & $-0.033^{\star}$ & -0.031 & -0.03 \\
& $(0.02)$ & $(0.02)$ & $(0.02)$ \\
\hline \multirow{2}{*}{4 months (before) } & $-0.041^{\star \star}$ & $-0.039^{\star}$ & $-0.039^{\star}$ \\
& $(0.02)$ & $(0.02)$ & $(0.02)$ \\
\hline \multirow{2}{*}{3 months (before) } & $-0.041^{\star \star}$ & $-0.038^{\star}$ & $-0.037^{\star}$ \\
& $(0.02)$ & $(0.02)$ & $(0.02)$ \\
\hline \multirow{2}{*}{2 months (before) } & $-0.043^{\star \star}$ & $-0.040^{\star \star}$ & $-0.039^{\star \star}$ \\
& $(0.02)$ & $(0.02)$ & $(0.02)$ \\
\hline \multirow{2}{*}{1 month (before) } & $-0.041^{\star}$ & $-0.042^{\star \star}$ & $-0.042^{\star \star}$ \\
& $(0.02)$ & $(0.02)$ & $(0.02)$ \\
\hline \multirow{2}{*}{ election month } & -0.030 & -0.021 & -0.022 \\
& $(0.02)$ & $(0.02)$ & $(0.02)$ \\
\hline \multirow{2}{*}{1 month (after) } & -0.005 & 0.004 & 0.004 \\
& $(0.02)$ & $(0.02)$ & $(0.02)$ \\
\hline
\end{tabular}




\begin{tabular}{|c|c|c|c|}
\hline \multirow{2}{*}{ Variables } & \multicolumn{3}{|c|}{ All Samples } \\
\hline & (1) & (2) & (3) \\
\hline 2 months (after) & $\begin{array}{l}-0.011 \\
(0.02)\end{array}$ & $\begin{array}{l}0.002 \\
(0.02)\end{array}$ & $\begin{array}{l}0.003 \\
(0.02)\end{array}$ \\
\hline 3 months (after) & $\begin{array}{l}-0.011 \\
(0.02)\end{array}$ & $\begin{array}{l}-0.0002 \\
(0.02)\end{array}$ & $\begin{array}{r}0.001 \\
(0.02)\end{array}$ \\
\hline 4 months (after) & $\begin{array}{c}0.011 \\
(0.03)\end{array}$ & $\begin{array}{l}-0.012 \\
(0.02)\end{array}$ & $\begin{array}{l}-0.011 \\
(0.02)\end{array}$ \\
\hline 5 months (after) & $\begin{array}{c}0.019 \\
(0.02)\end{array}$ & $\begin{array}{c}0.004 \\
(0.02)\end{array}$ & $\begin{array}{c}0.002 \\
(0.02)\end{array}$ \\
\hline 6 months (after) & $\begin{array}{c}0.006 \\
(0.02)\end{array}$ & $\begin{array}{l}-0.002 \\
(0.02)\end{array}$ & $\begin{array}{l}-0.002 \\
(0.02)\end{array}$ \\
\hline Inflation rate & & $\begin{array}{l}0.513^{\star} \\
(0.26)\end{array}$ & $\begin{array}{l}0.553^{\star} \\
(0.27)\end{array}$ \\
\hline log of dividend-price ratio & & $\begin{array}{l}-1.126 \\
(1.06)\end{array}$ & $\begin{array}{l}-1.344 \\
(1.12)\end{array}$ \\
\hline term spread & & $\begin{array}{l}-1.79 \\
(1.80)\end{array}$ & $\begin{array}{l}-1.671 \\
(1.84)\end{array}$ \\
\hline relative interest rate & & $\begin{array}{l}-1.585 \\
(0.95)\end{array}$ & $\begin{array}{l}-1.678^{*} \\
(0.94)\end{array}$ \\
\hline industrial production growth rate & & $\begin{array}{l}-0.170 \\
(0.22)\end{array}$ & $\begin{array}{l}-0.047 \\
(0.19)\end{array}$ \\
\hline U.S. industrial production growth rate & & & $\begin{array}{l}-0.314^{*} \\
(0.16)\end{array}$ \\
\hline constant & $\begin{array}{l}0.343^{\star \star *} \\
(0.00)\end{array}$ & $\begin{array}{l}0.383^{\star \star \star} \\
(0.05)\end{array}$ & $\begin{array}{l}0.385^{\star \star *} \\
(0.05)\end{array}$ \\
\hline $\begin{array}{l}\text { observations } \\
\text { R-squared } \\
\text { number of countries }\end{array}$ & $\begin{array}{r}8870 \\
0.002 \\
16\end{array}$ & $\begin{array}{r}7304 \\
0.034 \\
16\end{array}$ & $\begin{array}{r}7304 \\
0.038 \\
16\end{array}$ \\
\hline $\begin{array}{l}\text { H0: coefficients of two to one month (before) }=0 \\
\text { F-test } \\
\text { prob }>\text { F }\end{array}$ & $\begin{array}{l}4.76 \\
0.0250\end{array}$ & $\begin{array}{l}3.74 \\
0.0482\end{array}$ & $\begin{array}{l}3.38 \\
0.0613\end{array}$ \\
\hline
\end{tabular}

Note: Robust standard errors in parentheses, ${ }^{* * *} p<0.01,{ }^{* *} p<0.05,{ }^{*} p<0.1$.

The second column shows that nearly the same results are obtained, even when other control variables such as the inflation rate, log dividend-price ratio, term spread, relative interest rate, and industrial production growth rate are included in the regression. These variables are reported to have explanatory power for stock returns and are delayed for one month to avoid endogeneity. We have obtained similar results in the 
Figure 2. Coefficients of Before and After Election Dummy Variables

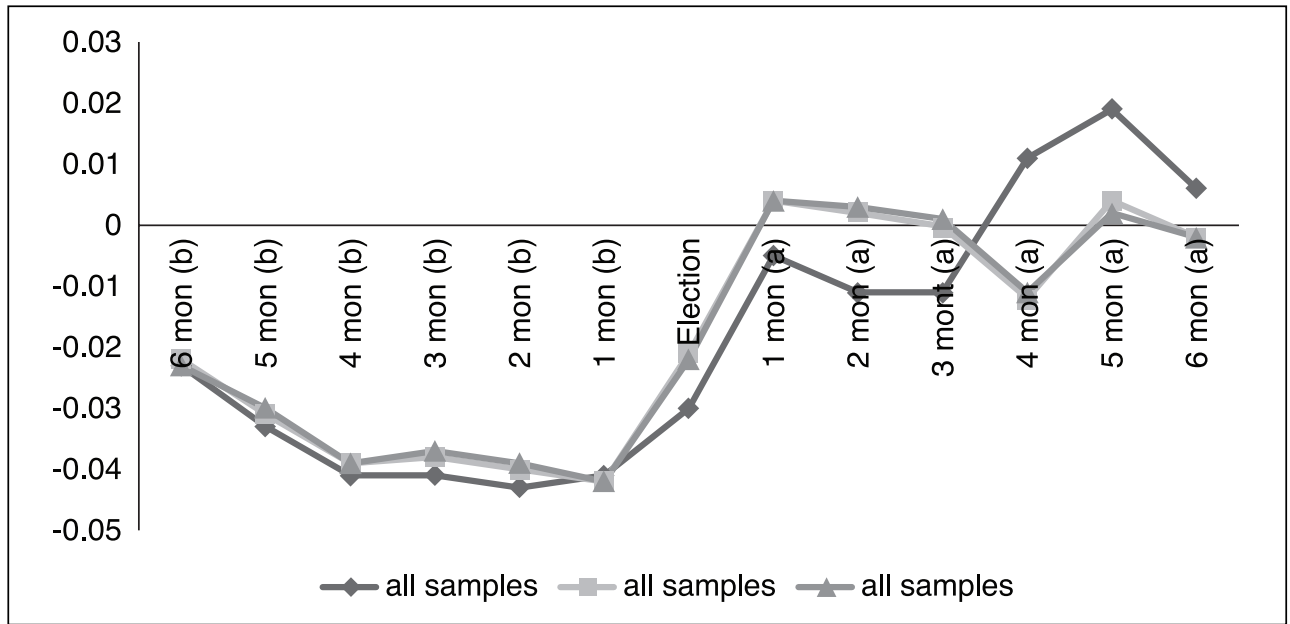

Note: This figure plots dummy variable coefficients from table 3.

third column, when the growth rate of the U.S. industrial production is added to control for the global business cycle. Since financial variables and macroeconomic variables can explain a small portion of the volatility in Schwert (1989), the nearly identical results after the inclusion of these control variables are consistent with the main finding in Schwert (1989).

These results are plotted in figure 2. In all three cases, the coefficients of time dummy variables decline steadily before an election, rise rapidly during the election month and immediately after the election, and then fluctuate around zero. Interesting issues emerge from these dynamic patterns. First, the dynamic pattern of the volatility is consistent with the premises reported in Pantzalis et al. (2000) and Wisniewski (2009). The declining trend in the coefficients for the time-dummy variables implies that the volatility declines as elections approach. Also, that these coefficients before an election are mostly negative suggests that the level of volatility is lower before election than that during non-election periods. The null hypothesis of $\delta_{-2}=\delta_{-1}=0$ can be rejected at the $10 \%$ significance level by the F-test, which is shown in the last row of table 3 . The results in figure 2 and table 3 imply that the dynamic pattern of the volatility is likely the main reason for the rise in stock prices and overpricing phenomena before elections, as indicated by the assertions in Pantzalis et al. (2000) and Wisniewski (2009).

Second, economists have searched for factors impacting stock market volatility since Schwert (1989) showed that macroeconomic and financial variables have limits in explaining the movements of volatility. The results in table 3 and figure 2 suggest 
that important political events, such as elections, can be considered a factor influencing the volatility in the stock market. One way to determine whether political events impact the stock market is to determine whether the movements of the volatility are similar to the uncertainty provided by elections. In many instances, the probable winner of an election becomes more apparent as election day approaches. Hence, if political elections are another source of uncertainty in the market, the volatility will decline as the uncertainty around election results decreases. In addition, the lower volatility level before elections may also be related to the lower perceived risk before elections, as described by the model in Loewenstein et al. (2001). Therefore, the declining trend in stock market volatility before elections and the lower volatility level before elections, as shown in figure 2 and table 3, implies that important political events such as elections are indeed a source of the volatility in the stock market.

Third, Pantzalis et al. (2000) find that stock prices rise prior to an election, and argue that this rise is related to the lower uncertainty immediately prior to the election. However, Bialkowski et al. (2008) report that stock markets are extremely vulnerable around elections in terms of the volatility. These seemingly inconsistent findings are also observed in our results of table 3 and figure 2. Table 3 and figure 2 show that the volatility declines steadily as elections approach, which is consistent with the argument by Pantzalis et al. (2000). However, we can also see that there is a rapid rise in volatility during the election month, which might reflect surprise by the election outcome or that the lower perceived risk returns to normal levels due to the discontinuation of promising policies and optimistic views before elections. As Pantzalis et al. (2000) and Bialkowski et al. (2008) use higher frequency data than the data in this study, we are not able to determine the exact timing of this turning point in the trend of the coefficients, but we clearly observe a rise in volatility during the election month, which supports the veracity of the finding in Bialkowski et al. (2008).

In summary, the dynamic behavior of volatility before elections appears to be consistent with the conjecture on the volatility made in Pantzalis et al. (2000) and by Wisniewski (2009). The rise of volatility during election months or immediately after elections is also in agreement with the findings in Bialkowski et al. (2008).

\section{Robustness Checks}

We then investigate whether the dynamic pattern of the volatility around electionsthe declining trend before, a rise during, and fluctuations after-is robust. First, we check whether the dynamic pattern of stock market volatility differs depending on which party wins an election. Santa-Clara and Valkanov (2003) demonstrate that the U.S. stock returns are much higher when Democrats are in the White House. In addition, 
Table 4. Robustness Tests: Rightist Party versus Leftist Party

\begin{tabular}{|c|c|c|c|c|}
\hline \multirow{2}{*}{ Variables } & \multicolumn{2}{|c|}{ Rightist Party Wins } & \multicolumn{2}{|c|}{ Leftist Party Wins } \\
\hline & $(1)$ & $(2)$ & (3) & $(4)$ \\
\hline 6 months (before) & $\begin{array}{l}-0.012 \\
(0.02)\end{array}$ & $\begin{array}{l}-0.032^{\star \star} \\
(0.01)\end{array}$ & $\begin{array}{l}-0.050^{\star} \\
(0.03)\end{array}$ & $\begin{array}{l}-0.044^{\star} \\
(0.02)\end{array}$ \\
\hline 5 months (before) & $\begin{array}{l}-0.026 \\
(0.02)\end{array}$ & $\begin{array}{l}-0.046^{\star \star \star} \\
(0.02)\end{array}$ & $\begin{array}{l}-0.062^{\star \star} \\
(0.03)\end{array}$ & $\begin{array}{l}-0.050^{*} \\
(0.03)\end{array}$ \\
\hline 4 months (before) & $\begin{array}{l}-0.031^{*} \\
(0.02)\end{array}$ & $\begin{array}{l}-0.050^{\star *} \\
(0.02)\end{array}$ & $\begin{array}{l}-0.071^{\star *} \\
(0.03)\end{array}$ & $\begin{array}{l}-0.062^{\star *} \\
(0.03)\end{array}$ \\
\hline 3 months (before) & $\begin{array}{l}-0.024 \\
(0.01)\end{array}$ & $\begin{array}{l}-0.045^{\star} \\
(0.03)\end{array}$ & $\begin{array}{l}-0.076^{\star \star} \\
(0.03)\end{array}$ & $\begin{array}{l}-0.056^{\star} \\
(0.03)\end{array}$ \\
\hline 2 months (before) & $\begin{array}{l}-0.023^{\star *} \\
(0.01)\end{array}$ & $\begin{array}{l}-0.032^{\star *} \\
(0.02)\end{array}$ & $\begin{array}{l}-0.076^{\star *} \\
(0.03)\end{array}$ & $\begin{array}{l}-0.060^{\star} \\
(0.03)\end{array}$ \\
\hline 1 month (before) & $\begin{array}{l}-0.019 \\
(0.01)\end{array}$ & $\begin{array}{l}-0.034 \\
(0.02)\end{array}$ & $\begin{array}{l}-0.084^{\star \star} \\
(0.03)\end{array}$ & $\begin{array}{l}-0.079^{\star \star} \\
(0.03)\end{array}$ \\
\hline election month & $\begin{array}{l}-0.019 \\
(0.01)\end{array}$ & $\begin{array}{l}-0.021 \\
(0.02) \\
\end{array}$ & $\begin{array}{l}-0.076^{\star \star \star} \\
(0.03)\end{array}$ & $\begin{array}{l}-0.066^{\star \star} \\
(0.03)\end{array}$ \\
\hline 1 month (after) & $\begin{array}{l}-0.002 \\
(0.02)\end{array}$ & $\begin{array}{l}-0.002 \\
(0.03)\end{array}$ & $\begin{array}{l}-0.032 \\
(0.03)\end{array}$ & $\begin{array}{l}-0.019 \\
(0.03)\end{array}$ \\
\hline 2 months (after) & $\begin{array}{l}-0.008 \\
(0.02)\end{array}$ & $\begin{array}{l}0.001 \\
(0.03)\end{array}$ & $\begin{array}{l}-0.03 \\
(0.02)\end{array}$ & $\begin{array}{l}-0.018 \\
(0.03)\end{array}$ \\
\hline 3 months (after) & $\begin{array}{l}-0.006 \\
(0.02)\end{array}$ & $\begin{array}{l}-0.008 \\
(0.02)\end{array}$ & $\begin{array}{l}-0.019 \\
(0.03)\end{array}$ & $\begin{array}{c}0.013 \\
(0.02)\end{array}$ \\
\hline 4 months (after) & $\begin{array}{l}-0.01 \\
(0.02)\end{array}$ & $\begin{array}{l}-0.012 \\
(0.03)\end{array}$ & $\begin{array}{c}0.037 \\
(0.07)\end{array}$ & $\begin{array}{l}-0.012 \\
(0.03)\end{array}$ \\
\hline 5 months (after) & $\begin{array}{l}0 \\
(0.02)\end{array}$ & $\begin{array}{l}-0.002 \\
(0.03)\end{array}$ & $\begin{array}{c}0.047 \\
(0.06)\end{array}$ & $\begin{array}{c}0.01 \\
(0.03)\end{array}$ \\
\hline 6 months (after) & $\begin{array}{l}-0.012 \\
(0.02)\end{array}$ & $\begin{array}{l}-0.013 \\
(0.02)\end{array}$ & $\begin{array}{c}0.03 \\
(0.04)\end{array}$ & $\begin{array}{c}0.014 \\
(0.03)\end{array}$ \\
\hline inflation rate & & $\begin{array}{l}0.423^{\star} \\
(0.22)\end{array}$ & & $\begin{array}{c}0.601 \\
(0.64)\end{array}$ \\
\hline log of dividend-price ratio & & $\begin{array}{l}-2.027 \\
(1.91)\end{array}$ & & $\begin{array}{l}-1.066 \\
(1.14)\end{array}$ \\
\hline term spread & & $\begin{array}{l}-1.194 \\
(0.79)\end{array}$ & & $\begin{array}{l}-1.802 \\
(3.39) \\
\end{array}$ \\
\hline relative interest rate & & $\begin{array}{l}-0.982 \\
(0.71)\end{array}$ & & $\begin{array}{l}-1.841^{*} \\
(0.92)\end{array}$ \\
\hline industrial production growth rate & & $\begin{array}{l}-0.066 \\
(0.08)\end{array}$ & & $\begin{array}{l}-0.15 \\
(0.40)\end{array}$ \\
\hline U.S. industrial production growth rate & & $\begin{array}{l}-0.233^{*} \\
(0.13)\end{array}$ & & $\begin{array}{l}-0.305 \\
(0.33)\end{array}$ \\
\hline constant & $\begin{array}{l}0.308^{\star \star \star} \\
(0.00)\end{array}$ & $\begin{array}{l}0.387^{\star \star \star} \\
(0.07)\end{array}$ & $\begin{array}{l}0.379^{\star \star *} \\
(0.01)\end{array}$ & $\begin{array}{l}0.394^{\star \star \star} \\
(0.08)\end{array}$ \\
\hline $\begin{array}{l}\text { observations } \\
\text { R-squared } \\
\text { number of countries }\end{array}$ & $\begin{array}{r}4818 \\
0.002 \\
15\end{array}$ & $\begin{array}{r}3821 \\
0.065 \\
15\end{array}$ & $\begin{array}{r}3788 \\
0.006 \\
15\end{array}$ & $\begin{array}{r}3231 \\
0.038 \\
15\end{array}$ \\
\hline
\end{tabular}

Note: Robust standard errors in parentheses, ${ }^{* \star *} p<0.01,{ }^{* \star} p<0.05,{ }^{*} p<0.1$. 
Figure 3. Coefficients from Rightist and Leftist Party Samples

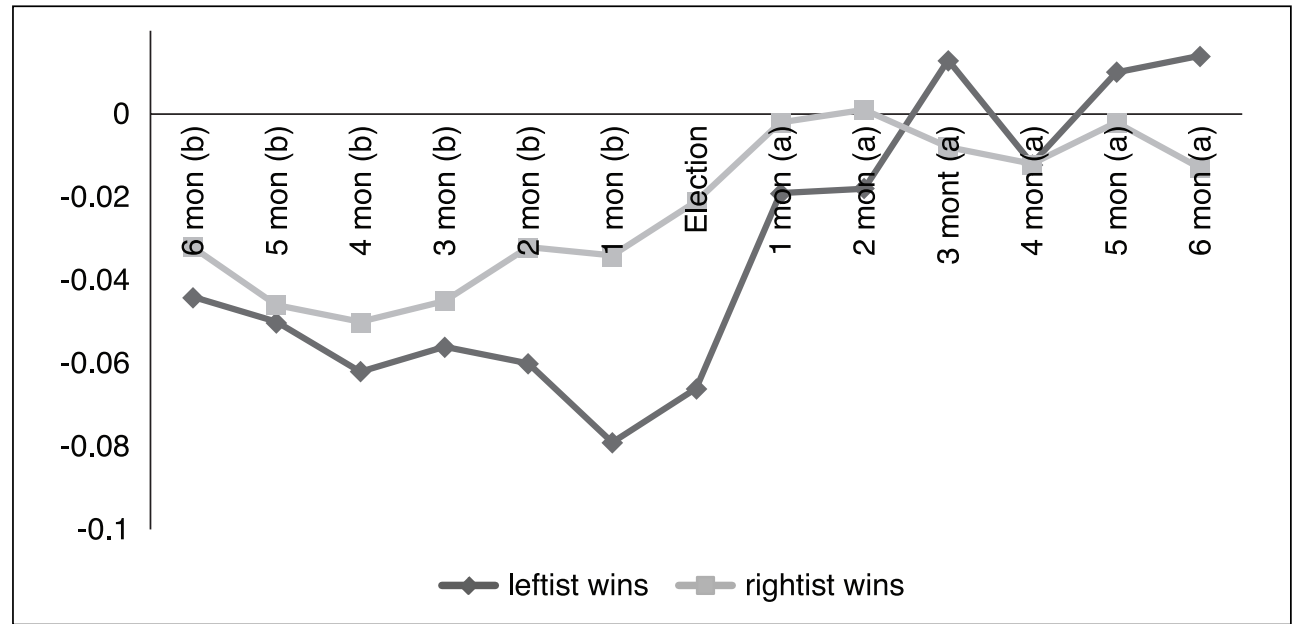

Note: This figure plots dummy variable coefficients from columns 2 and 4 of table 4 .

Swank and Betz (2003) show that universal welfare state and economic conditions such as capital mobility and trade openness are related with the popularity of rightwing parties. Hence, the volatility around election time may show different dynamics depending on who is expected to win the election. In order to examine this possibility, we have divided our sample into two subsets: cases in which the rightist party wins the elections, and cases in which the leftist party wins. After separation of the sample, we run the panel regression with country fixed effects again. The results for the rightist party wins are presented in the first and second column of table 4, while the results for leftist party wins are shown in the third and fourth columns. The results in the first and third column of table 4 are from the regression of the volatility on time- and countrydummy variables only, whereas the results in the second and fourth columns are from the regression with time- and country-dummy variables along with other control variables. Similar to the results in table 3, we find a declining trend in the time-dummy coefficients before elections and those coefficients are significantly negative over a time range between six months before an election to the election month. We also observe that the coefficients begin to rise during the election month and become insignificant right at election time and one month after. Movements of these coefficients are plotted in figure 3.

Second, we also investigate whether the results vary over time. The results presented in table 2 imply that the properties of stock return distribution seem quite different in the pre-and post-1980 samples. There are reasons for this change: the globalization of stock markets due to capital liberalization, a lower barrier to stock market participation 
Table 5. Robustness Tests: Different Sample Periods and Sample from Countries Whose Election Dates Are Not Fixed

\begin{tabular}{|c|c|c|c|}
\hline Variables & $\begin{array}{l}\text { Pre-1980 } \\
\text { (1) }\end{array}$ & $\begin{array}{l}\text { Post-1980 } \\
\text { (2) }\end{array}$ & $\begin{array}{l}\text { Election dates } \\
\text { not fixed } \\
\text { (3) }\end{array}$ \\
\hline 6 months (before) & $\begin{array}{l}-0.036^{\star \star} \\
(0.01)\end{array}$ & $\begin{array}{l}-0.003 \\
(0.03)\end{array}$ & $\begin{array}{l}-0.024 \\
(0.02)\end{array}$ \\
\hline 5 months (before) & $\begin{array}{l}-0.052^{\star \star \star} \\
(0.02)\end{array}$ & $\begin{array}{l}-0.008 \\
(0.03)\end{array}$ & $\begin{array}{l}-0.032 \\
(0.02)\end{array}$ \\
\hline 4 months (before) & $\begin{array}{l}-0.058^{\star \star} \\
(0.02)\end{array}$ & $\begin{array}{l}-0.022 \\
(0.02)\end{array}$ & $\begin{array}{l}-0.039 \\
(0.02)\end{array}$ \\
\hline 3 months (before) & $\begin{array}{l}-0.064 \\
(0.04)\end{array}$ & $\begin{array}{l}-0.019 \\
(0.02)\end{array}$ & $\begin{array}{l}-0.039 \\
(0.03)\end{array}$ \\
\hline 2 months (before) & $\begin{array}{l}-0.064^{\star \star} \\
(0.02)\end{array}$ & $\begin{array}{l}-0.024 \\
(0.02)\end{array}$ & $\begin{array}{l}-0.040^{\star} \\
(0.02)\end{array}$ \\
\hline 1 month (before) & $\begin{array}{l}-0.060^{\star \star} \\
(0.02)\end{array}$ & $\begin{array}{l}-0.025 \\
(0.02)\end{array}$ & $\begin{array}{l}-0.041 \\
(0.02)\end{array}$ \\
\hline election month & $\begin{array}{l}-0.048 \\
(0.03)\end{array}$ & $\begin{array}{l}-0.002 \\
(0.03)\end{array}$ & $\begin{array}{l}-0.016 \\
(0.03)\end{array}$ \\
\hline 1 month (after) & $\begin{array}{l}-0.017 \\
(0.03)\end{array}$ & $\begin{array}{c}0.022 \\
(0.03)\end{array}$ & $\begin{array}{c}0.008 \\
(0.03)\end{array}$ \\
\hline 2 months (after) & $\begin{array}{l}-0.019 \\
(0.03)\end{array}$ & $\begin{array}{c}0.017 \\
(0.03)\end{array}$ & $\begin{array}{c}0.008 \\
(0.02)\end{array}$ \\
\hline 3 months (after) & $\begin{array}{l}-0.022 \\
(0.03)\end{array}$ & $\begin{array}{c}0.017 \\
(0.02)\end{array}$ & $\begin{array}{l}0.003 \\
(0.02)\end{array}$ \\
\hline 4 months (after) & $\begin{array}{l}-0.037 \\
(0.03)\end{array}$ & $\begin{array}{c}0.008 \\
(0.02)\end{array}$ & $\begin{array}{l}-0.012 \\
(0.02)\end{array}$ \\
\hline 5 months (after) & $\begin{array}{l}-0.034 \\
(0.03)\end{array}$ & $\begin{array}{c}0.025 \\
(0.02)\end{array}$ & $\begin{array}{c}0.011 \\
(0.02)\end{array}$ \\
\hline 6 months (after) & $\begin{array}{l}-0.036 \\
(0.02)\end{array}$ & $\begin{array}{c}0.02 \\
(0.02)\end{array}$ & $\begin{array}{c}0.001 \\
(0.02)\end{array}$ \\
\hline inflation rate & $\begin{array}{l}0.773^{\star} \\
(0.40)\end{array}$ & $\begin{array}{c}0.729 \\
(0.42)\end{array}$ & $\begin{array}{l}0.668^{\star \star} \\
(0.30)\end{array}$ \\
\hline log of dividend-price ratio & $\begin{array}{l}1.906 \\
(1.42)\end{array}$ & $\begin{array}{l}-1.208 \\
(1.35)\end{array}$ & $\begin{array}{l}-1.197 \\
(1.15)\end{array}$ \\
\hline term spread & $\begin{array}{c}0.477 \\
(2.26)\end{array}$ & $\begin{array}{l}-3.407 \\
(1.94)\end{array}$ & $\begin{array}{l}-1.397 \\
(2.03)\end{array}$ \\
\hline relative interest rate & $\begin{array}{l}-0.104 \\
(0.53)\end{array}$ & $\begin{array}{l}-2.473^{\star} \\
(1.26)\end{array}$ & $\begin{array}{l}-0.954 \\
(0.78)\end{array}$ \\
\hline industrial production growth rate & $\begin{array}{l}-0.043 \\
(0.14)\end{array}$ & $\begin{array}{l}0.329 \\
(0.39)\end{array}$ & $\begin{array}{c}0.037 \\
(0.22)\end{array}$ \\
\hline U.S. industrial production growth rate & $\begin{array}{l}-0.495^{\star} \\
(0.24)\end{array}$ & $\begin{array}{l}-0.077 \\
(0.24)\end{array}$ & $\begin{array}{l}-0.318 \\
(0.19)\end{array}$ \\
\hline constant & $\begin{array}{c}0.164 \\
(0.10)\end{array}$ & $\begin{array}{l}0.419^{\star \star \star} \\
(0.04)\end{array}$ & $\begin{array}{l}0.376^{\star \star \star} \\
(0.06)\end{array}$ \\
\hline $\begin{array}{l}\text { observations } \\
\text { R-squared } \\
\text { number of countries }\end{array}$ & $\begin{array}{r}2741 \\
0.178 \\
13\end{array}$ & $\begin{array}{r}4563 \\
0.034 \\
15\end{array}$ & $\begin{array}{r}6152 \\
0.034 \\
14\end{array}$ \\
\hline
\end{tabular}

Note: Robust standard errors in parentheses, ${ }^{\star \star \star} p<0.01,{ }^{\star \star} p<0.05,{ }^{*} p<0.1$. 
Figure 4. Coefficients from Different Periods and Samples from Countries Whose Election Dates Are Not Fixed

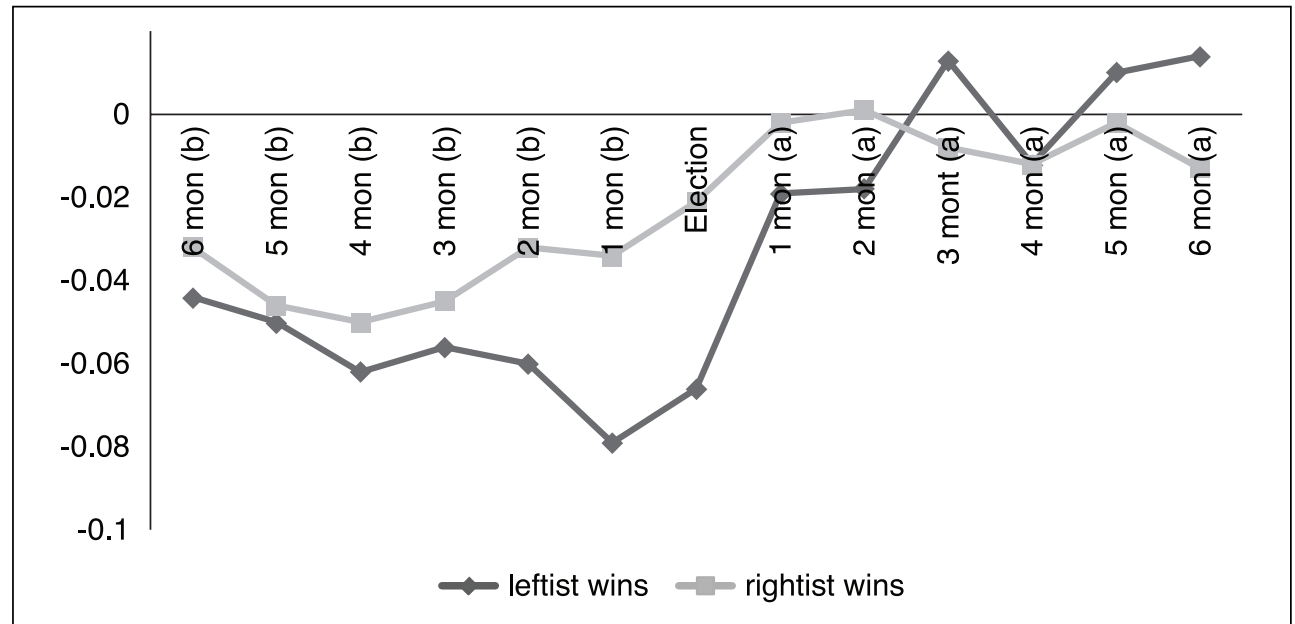

Note: This figure plots dummy variable coefficients from table 5.

due to the development of information technology, and higher economic integration across countries. The influential book by Prasad et al. (2003) has pointed out that the wave of financial globalization has occurred since the 1980s with a surge in capital flows among industrial countries. Thus, it is natural to separate samples into the preand the post- globalization periods and the cutting year is 1980. In order to examine the robustness of the results over time, we divided our sample into two sub-samples: the first includes only observations from pre- 1980,6 and the other includes only the post-1980 observations. Then, we run the panel regression with country fixed effects as in Tables 3 and 4 . The results are presented in table 5 and figure 4 . Consistent with previous results, we obtain a declining trend in the coefficients before elections and a quick recovery during election months. The coefficients are not significant when post1980 observations are used. However, most coefficients before elections are significantly negative when pre-1980 observations are used. ${ }^{7}$ Although the results are slightly different from the pre-1980 sample, the declining trend in the coefficients and negative coefficients before elections appear robust, regardless of whether the data was collected in the preor post- 1980.

Among our sample countries, United States and Sweden have elections at fixed

6. To secure enough observations in both periods, we select 1980 as the dividing point.

7. We run the same regressions as in table 4 with the pre-1980 sample. We find that the pre1980 sample provides similar results as in table 4. 
timing with pre-determined election dates. However, other countries' elections dates are not fixed, which may create endogeneity issues. Thus, we examines whether the existence of fixed timing in elections brings different estimation results. We ran regressions for 14 countries excluding U.S. and Sweden and reports the results in the last column of table 5 and figure 4 . The sample with not fixed timing countries also show similar dynamic patterns in the previous Tables.

In summary, movements of time-dummy coefficients before, during, and after elections are quite similar to those in the previous sub-section and do not appear to depend on which party wins elections or when data was collected (the pre- and post-1980) or the fixed election timing, though there are some differences in the significance level for those coefficients.

\section{CONCLUSION}

We investigated movements of stock market volatility during election periods (the one-year around an election) using data from 16 countries. We have found that the volatility declines over time as elections approach, which is consistent with the results in Pantzalis et al. (2000), that the uncertainty of election outcomes decreases as elections approach. We have also found that the level of volatility is lower before elections than during non-election periods, which is in agreement with the Wisniewski (2009), that investors' perceived risk is lower before elections due to promising policies by politicians. We observe that the stock market volatility rises quite quickly during election months and immediately after, which is consistent with the phenomenon reported by Bialkowski et al. (2008). This rise might be due to surprise at the outcome of the election or due to the discontinuation of bright promises made before elections. These dynamic patterns in the volatility during election periods will be helpful in making investment decisions and adjusting portfolios during election periods.

\section{REFERENCES}

Bialkowski, J., Gottschalk, K. \& Wisniewski, T. P. 2008. Stock market volatility around national elections. Journal of Banking and Finance, 32(9): 1941-1953.

Bollerslev, T. 1986. Generalized autoregressive conditional heteroskedasticity. Journal of Econometrics, 31(3): 307-327.

Chung, J \& Jung. K. 2009. Political business cycles and their policy implications: An extension of Alesina's model. Korean Journal of Policy Studies, 24(1): 127-147. 
Döpke, J. \& Pierdzioch, C. 2006. Politics and the stock market: Evidence from Germany. European Journal of Political Economy, 22(4): 925-943.

Engle, R.. 1982. Autoregressive conditional heteroscedasticity with estimates of the variance of United Kingdom inflation. Econometrica, 50(4): 987-1007.

Gärtner, M. \& Wellershoff, K. W. 1995. Is there an election cycle in American stock returns? International Review of Economics and Finance, 4(4): 387-410.

Herbst, A. F. \& Slinkman, C. W. 1984. Political-economic cycles in the U.S. stock market. Financial Analyst Journal, 40(2): 38-44.

Huang, R. D. 1985. Common stock returns and presidential elections. Financial Analyst Journal, 41(2): 58-61.

Leblang, D. \& Mukhurjee, B. 2004. Presidential elections and the stock market: Comparing Markov-switching and fractionally integrated GARCH models of volatility. Political Analysis, 12(3): 296-322.

Leblang, D \& Mukhurjee, B. 2005. Government partisanship, elections, and the stock market: Examining American and British stock returns, 1930-2000. American Journal of Political Science, 49(4): 780-802.

Loewenstein, G. F., Hsee, C. K., Weber, E. U. \& Welch, N. 2001. Risk as feelings. Psychological Bulletin, 127(2): 267-286.

Pantzalis, C., Stangeland, D. A. \& Turtle, H. J. 2000. Political elections and the resolution of uncertainty: The international evidence. Journal of Banking and Finance, 24(10): 1575-1604.

Prasad, E. S., Rogoff, K., Wei, S. \& Kose, M. A. 2003. Effects of financial globalization on developing countries: Some empirical evidence. Washington, DC: International Monetary Fund

Santa-Clara, P. \& Valkanov, R. 2003. Political cycles and the stock market. Journal of Finance, 58(5): 1841-1872.

Schwert, G. W. 1989. Why does stock market volatility change over time? Journal of Finance, 44(5): 1115-1153.

Shiller, R. J. 1981. Do stock prices move too much to be justified by subsequent changes in dividends? American Economic Review, 71(3): 421-436.

Swank, D. 2010. Electoral, legislative, and government strength of political parties by ideological group in capitalist democracies, 1950-2006: A database data set. Retrieved on August 16, 2012, from http://www.marquette.edu/polisci/faculty_ swank.shtml.

Swank, D. \& Betz, H-G. 2003. Globalization, the welfare state and right-wing populism in Western Europe. Socio-Economic Review, 1(2): 215-245.

Wisniewski, T. P. 2009. Can political factors explain the behavior of stock prices beyond the standard present value models? Applied Financial Economics, 19(23): 1873-1884. 